\title{
Applying Decomposed Theory of Planned Behaviour towards a Comprehensive Understanding of Social Network Usage in Saudi Arabia
}

\author{
Waleed A. Al-Ghaith \\ Shaqra University /Department of Information Systems, Riyadh, Saudi Arabia \\ E-mail:w.alghaith@su.edu.sa
}

\begin{abstract}
This study examines the individuals' participation intentions and behaviour on Social Networking Sites. For this purpose, the Decomposed Theory of Planned Behaviour is utilized. Data collected from a survey of 1100 participants and distilled to 657 usable sets has been analysed to assess the predictive power of Decomposed Theory of Planned Behaviour' model via structural equation modelling. The results show that attitude and subjective norm have significant effect on the participation intention of adopters. Further, the results show that participation intention has significant effect on participation behaviour. However, the study findings also show that perceived behavioural control has no significant effect on participation intention or behaviour of adopters. The model adopted in this study explains $47 \%$ of the variance in "Participation Intentions" and $36 \%$ of the variance in "Participation Behaviour". Participation of behavioural intention in the model' explanatory power was the highest amongst the constructs (able to explain 14.6\% of usage behaviour). While, "attitude" explain around $9 \%$ of SNSs usage behaviour.
\end{abstract}

Index Terms-Adoption, Saudi Arabia, Social networking sites, Decomposed Theory of Planned Behaviour, DTPB, Usage.

\section{INTRODUCTION}

Since it's born, the Internet and its technologies such as the World Wide Web with Web 1.0 and then Web 2.0 present various forms of social interaction and activities. Web 2.0 Websites including social networking sites such as Twitter and Facebook, and video sharing sites such as YouTube refers to the second generation of the World Wide Web that facilitates information sharing and collaboration. A Social Network Sites (SNSs) is a platform allows users to build social relations with the people within and beyond their social circle ([20], [8]). SNSs such as Facebook, Twitter and LinkedIn, each of which has seen dramatic proliferation in popularity. Due to this popularity and its impact on individuals' daily lives, the SNSs have captured the attention of researchers
[30].

Many studies have examined SNS using a diversity of methodologies from multiple disciplines. Scholars have investigated many studies' topics in this context, for instance the formation and maintenance of social relationships [16] and industry competition dynamics on SNS [17]. Thus, this study systematically examines what factors contribute to SNS usage. This effort, which examined why individuals adopt SNS, matches to one of the five core research areas which forming the information systems discipline as identified by Sidorova, et al., [27]: (1) Information technology and organizations, (2) Information technology systems development, (3) Information technology and individuals, (4) Information technology and markets, and (5) Information technology and groups.

The IT and individuals examines primarily psychological aspects of human-computer interactions, focusing on research themes such as individual technology acceptance, IT adoption, HR issues in IS, computer self-efficacy, trust, and website design. Therefore, this study represents a mainstream area of IS research, contributing to the development of the discipline.

This study participates in this effort, and contributes to the literature by focusing on the determinants of SNS usage. One well-validated decision-making model that may provide an appropriate framework to understanding and predicting people's use of SNSs is the Decomposed Theory of Planned Behaviour (DTPB). Thus, in this study, we use the Decomposed Theory of Planned Behaviour (DTPB) to understand the Social Network use behaviour in Saudi Arabia. Data collected from a survey of 1100 participants and distilled to 657 usable sets has been analysed to assess the predictive power of DTPB model via structural equation modelling.

The paper proceeds as follows. In section 2, we review the theoretical model; DTPB and presents the proposed hypotheses along with the study model. In section 3, the methods of analysis are presented. The results of the study are then presented in Section 4. Thereafter, an equation has been formulated and used to calculate the participation of every model's construct in the model's explanatory power is presented along with a discussion of 
the results in Section 5. Conclusion has been presented in the sixth section. Section 7 is devoted to highlight the implications of the current study to theory and practice. Section 8 highlights the study limitations and link it with future research avenues.

\section{RESEARCH MODEL AND HYPOTHESES DEVELOPMENT}

\section{A. Decomposed Theory of Planned Behaviour (DTPB)}

Taylor and Todd [28] proposed a model known as the Decomposed Theory of Planned Behaviour (DTPB), which is a decomposed version of the TPB containing several constructs from the Technology Acceptance Model (TAM) ([12], [13]) and Diffusion of innovation theory (DOI) proposed by Everett Rogers (1983) [26]. It provides the same fit as the pure Theory of Planned Behaviour (TPB) model but has a somewhat better predictive power relative to the TAM and TPB models [28]. According to Taylor and Todd "the decomposed Theory of Planned Behaviour provides a fuller understanding of behavioural intention by focusing on the factors that are likely to influence systems use" ([28], p. $144)$ and as "it renders more transparent and easier to grasp the relations among beliefs, attitudes and intentions, it enables application of the model to a variety of situations" ([18], p. 76). In the DTPB, attitudinal beliefs, normative beliefs, control beliefs are broken down into constructs extracted from the literature and the TAM/DOI theories decomposing the attitudinal belief structure to include "perceived usefulness", "perceived ease of use" and "compatibility". Scholars have suggested that normative belief could be decomposed into relevant reference groups such as peers, superiors, and subordinates and that each may have differing views on the use of IT. Thus, two groups (peers and superiors) have been used by Taylor and Todd [28] to represent the decomposition of normative belief structures. While the control beliefs structure can be decomposed into two groups, self-efficacy and facilitating conditions [9]. Selfefficacy is related to the perceived ability of using a new technology, whereas the facilitating conditions construct provides two dimensions for control beliefs: one relating to resource factors such as time and money and the other focusing on technology compatibility issues that could limit usage ([28], [18], [9]) (see Fig. 1). Thus, the study hypotheses were developed based on DTPB model hypotheses.

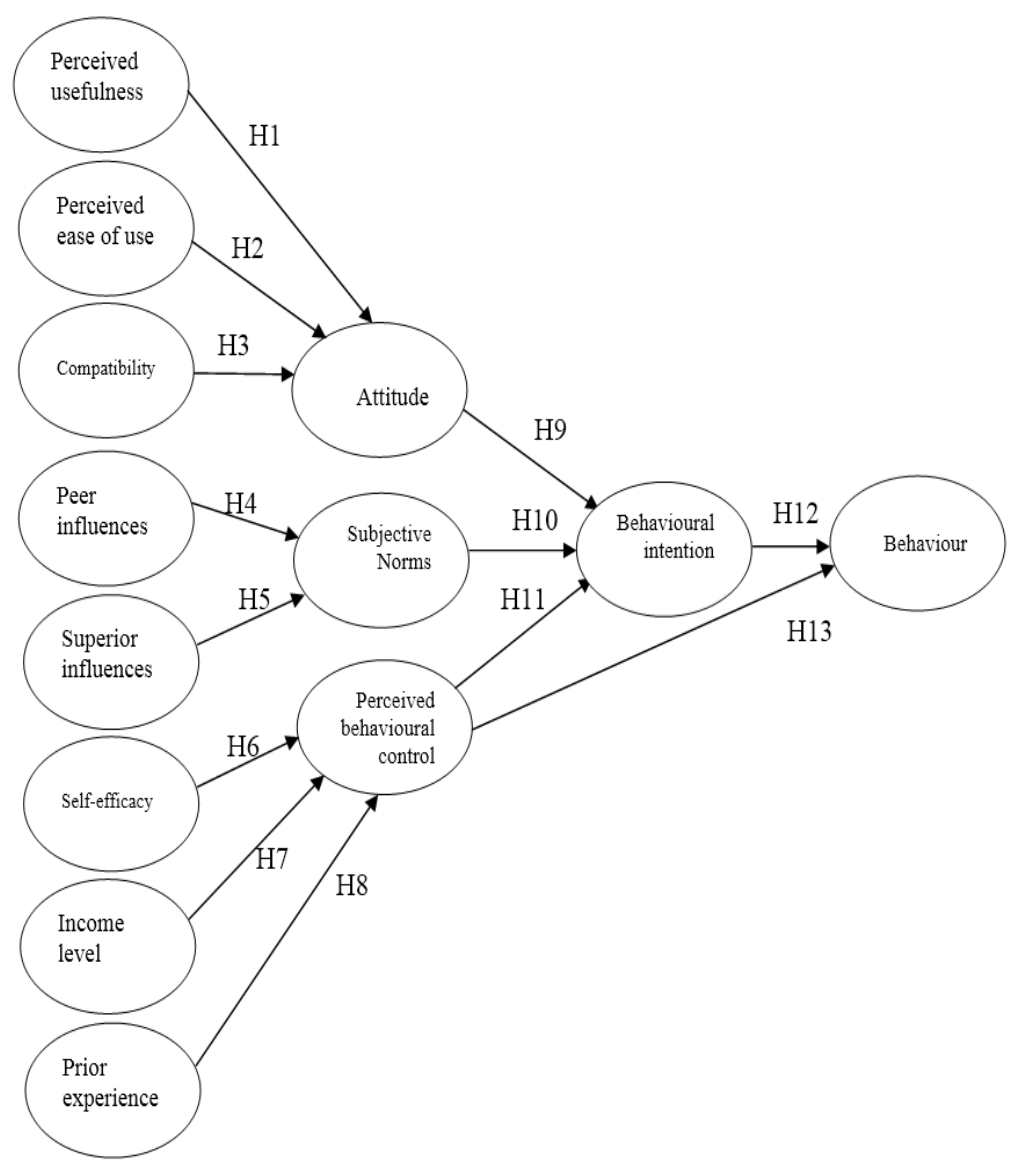

Fig.1. The study model (DTPB).

Hypothesis 1. User perceived usefulness will positively influence user attitude.

Hypothesis 2. User perceived ease of use will positively influence user attitude.
Hypothesis 3. Compatibility will positively influence user attitude.

Hypothesis 4. Peer influences will positively influence subjective norms. 
Hypothesis 5. Superior influences will positively influence subjective norms.

Hypothesis 6. Self-efficacy will positively influence perceived behavioural control.

Hypothesis 7. Income level will positively influence perceived behavioural control.

Hypothesis 8. Prior experience will positively influence perceived behavioural control.

Hypothesis 9. User attitude will positively influence user behavioural intention.

Hypothesis 10. Subjective norms will positively influence user behavioural intention.

Hypothesis 11. Perceived behavioural control will positively influence user behavioural intention.

Hypothesis 12. User behavioural intention will positively influence user behaviour.

Hypothesis 13. Perceived behavioural control will positively influence user behaviour.

\section{METHODOLOGY}

\section{A. Measurement}

Table 1. List of items by construct

\begin{tabular}{|c|c|c|}
\hline Construct & Items & Adapted from \\
\hline $\begin{array}{l}\text { Behavioural } \\
\text { intention (BI) }\end{array}$ & $\begin{array}{l}\text { BI1. I intend to use SNS website in } \\
\text { next three months. } \\
\text { BI2. I expect my use of the SNS } \\
\text { website to continue in the future. }\end{array}$ & {$[28],[24],[3]$.} \\
\hline $\begin{array}{l}\text { Subjective } \\
\text { Norm } \\
\text { (SN) }\end{array}$ & $\begin{array}{l}\text { SN1. My friends would think } \\
\text { that I should use SNS website. } \\
\text { SN2. My colleagues/classmates } \\
\text { would think that I should use } \\
\text { SNS website. } \\
\text { SN3. People who are important } \\
\text { to me would think that I should } \\
\text { use SNS website. }\end{array}$ & [28], [15], [3]. \\
\hline $\begin{array}{l}\text { Attitude } \\
\text { (AT) }\end{array}$ & $\begin{array}{l}\text { AT1. I have positive opinion in } \\
\text { SNS website. } \\
\text { AT2. I think usage of SNS } \\
\text { website is good for me } \\
\text { AT3. I think usage of SNS } \\
\text { website is appropriate for me }\end{array}$ & {$[12],[1],[3]$.} \\
\hline $\begin{array}{c}\text { Perceived } \\
\text { behavioural } \\
\text { control (PBC) }\end{array}$ & $\begin{array}{l}\text { PBC1. Using SNS is entirely } \\
\text { within my control } \\
\text { PBC2. Whether or not I use SNS } \\
\text { is entirely up to me }\end{array}$ & {$[28],[3]$.} \\
\hline $\begin{array}{l}\text { Perceived } \\
\text { usefulness } \\
\quad(\mathrm{PU})\end{array}$ & $\begin{array}{l}\text { PU1. SNS is more convenient than } \\
\text { other traditional social networks } \\
\text { options } \\
\text { PU2. SNS makes it easier to find } \\
\text { information and people. } \\
\text { PU3. SNS improves my information } \\
\text { and people seeking } \\
\text { PU4. SNSs help me to find } \\
\text { information more quickly } \\
\text { PU5. I think that SNSs is useful. } \\
\text { Overall, I think that using the } \\
\text { SNSs is advantageous. }\end{array}$ & [28], [24], \\
\hline $\begin{array}{l}\text { Perceived Ease } \\
\text { of Use }\end{array}$ & $\begin{array}{l}\text { ES1. Learning to use SNS was easy } \\
\text { for me }\end{array}$ & [28], [24]. \\
\hline
\end{tabular}

\begin{tabular}{|c|c|c|}
\hline Construct & Items & Adapted from \\
\hline (ES) & $\begin{array}{l}\text { ES2. I find SNS easy to use } \\
\text { ES3. English language is not a barrier } \\
\text { when I use SNS }\end{array}$ & \\
\hline $\begin{array}{c}\text { Compatibility } \\
\text { (COM) }\end{array}$ & $\begin{array}{l}\text { COM1. SNS is compatible with } \\
\text { my lifestyle } \\
\text { COM2. Using SNS fits well with } \\
\text { the way I like to accomplish my } \\
\text { needs } \\
\text { COM3. Using SNS is compatible } \\
\text { with my religious and cultural } \\
\text { aspects }\end{array}$ & [28], [24]. \\
\hline $\begin{array}{l}\text { Peer Influences } \\
\quad \text { (PNF) }\end{array}$ & $\begin{array}{l}\text { PNF1. My friends or my } \\
\text { colleagues/classmates would } \\
\text { think that I should use SNSs. } \\
\text { PNF2. Generally speaking, I } \\
\text { want to do what my friends or } \\
\text { my colleagues/classmates think } \\
\text { I should do. }\end{array}$ & [28] \\
\hline $\begin{array}{l}\text { Superior } \\
\text { Influences } \\
\text { (SNF) }\end{array}$ & $\begin{array}{l}\text { SNF1. My professors or parents } \\
\text { or managers would think that I } \\
\text { should use SNSs. } \\
\text { SNF2. Generally speaking, I } \\
\text { want to do what my professors } \\
\text { or parents or managers think I } \\
\text { should do. } \\
\text { SNF3. I will have to use the SNS } \\
\text { because my professors or } \\
\text { parents or managers require it. }\end{array}$ & [28] \\
\hline $\begin{array}{l}\text { Self-efficacy } \\
\text { (SE) }\end{array}$ & $\begin{array}{l}\text { SE1. I can use SNS website even if } \\
\text { there was no one around } \\
\text { to show me how to do it } \\
\text { SE2. I can use SNS website with only } \\
\text { the online help function } \\
\text { for assistance } \\
\text { SE3. If I wanted to, I could easily use } \\
\text { any of SNS website on } \\
\text { my own. } \\
\text { SE4. I would be able to use SNS } \\
\text { website even if I had never } \\
\text { used a system like it before }\end{array}$ & [28] \\
\hline Income (INC) & $\begin{array}{ll}\text { INC1. } & \text { Your income (per month) } \\
\text { INC2. } & \text { You consider yourself as a } \\
\text { rich person }\end{array}$ & [4] \\
\hline $\begin{array}{l}\text { Prior } \\
\text { Experience } \\
\text { (PEX) }\end{array}$ & $\begin{array}{l}\text { PEX1. I have a great deal of } \\
\text { experience using the SNS } \\
\text { PEX2. I am extremely skilled at } \\
\text { using the SNS websites } \\
\text { PEX3. I know how to find what I } \\
\text { am looking for on the SNS } \\
\text { websites. }\end{array}$ & [25] \\
\hline $\begin{array}{l}\text { SNS Usage } \\
\text { (US) }\end{array}$ & $\begin{array}{l}\text { US1. On average, each week I } \\
\text { use my SNS website often } \\
\text { US2. For each log session, I use } \\
\text { my SNS website long } \\
\text { US3. On my SNS, I often post } \\
\text { something } \\
\text { US4. On my SNS, I often view } \\
\text { something } \\
\text { US5. On my SNS, I often share } \\
\text { something } \\
\text { US6. On my SNS, I often reply } \\
\text { to others }\end{array}$ & [4], [29] \\
\hline
\end{tabular}


Identifying the concepts or constructs that a researcher intents to measure, and then choose appropriate measuring systems to measure those constructs is essential and has a significant impact on the accuracy of findings [33]. The items used in the survey instrument to measure the constructs were identified and adopted from prior research; particularly from IS research, in order to ensure the face (content) validity of the scale used. The items were widely used in the majority of prior studies indicating potential subjective agreement among researchers that these measuring instruments logically appear to reflect accurate measure of the constructs of interest. Table 1 lists the items developed for each construct in this study as well as set of prior studies where these items have been adopted from.

\section{B. Data Collection Procedures}

Data for this study were collected in two stages (6 months apart), from samples stratified into gender groups, by means of a survey conducted in Saudi Arabia in 2014. This type of sampling technique has been chosen due to the difficulty of drawing an actual representative sample in Saudi Arabia. Most houses in Saudi Arabia have not their own mail boxes and postal services are not available for every house. Moreover, due to the conservative nature of Saudi Arabian society, it is hard to approach women in Saudi Arabia. Therefore, stratified samples were drawn from numerous areas in the country. Female relatives were also engaged to distribute questionnaires to the female strata besides using electronic means to guarantee reaching females as well as males. The survey questionnaires were distributed to 1100 participants (550 male and 550 female). A total of 421 responses were received from male participants and 367 from female participants. After checking the data for validity, 657 were deemed fit for use in the analysis.

\section{DATA ANALYSIS AND RESULTS}

\section{A. Reliability and validity}

A reliability and internal consistency test was performed using data obtained from the pilot study of each construct in the instrument. The alpha values from the data obtained ranged from .876 to .981 with an overall alpha value of .941. Table 2 shows the Cronbach's alpha reliability of constructs in the study. The result indicated that all constructs of the model were reliable. Therefore, the internal consistency of the instrument was acceptable.

The Kaiser-Meyer-Olkin (KMO) and principal component factor analysis were conducted to examine the adequacy of the study sample and the validity of the study instrument, respectively. As the value of KMO was 0.803 as in Table 3 , the study sample was considered adequate and the appropriateness of using principal component factor analysis on the collected data was assured.

\section{B. Hypotheses testing}

In this study DTPB model has been applied to understand the Social Network use behaviour in Saudi Arabia. This model can be constituted through the test of 13 hypotheses. These hypotheses identify the relationship among factors as independent variables that impact adoption behaviour. Each accepted hypothesis represents an explanation of usage behaviour as dependent variables. Explanations are nomothetic and advance via deductive reasoning. The study hypotheses were tested using multiple regression analysis.

First, the three independent variables (i.e., "Perceived usefulness", "Perceived Ease of Use" and "Compatibility" were regressed on "Attitude". As in Fig. 2, it was found that "Perceived usefulness" $(\beta=0.312$, Standardized path coefficient, $p<0.001)$ and "Perceived Ease of Use" $(\beta=$ 0.585, Standardized path coefficient, $\mathrm{p}<0.001)$ are significantly and positively related to "Attitude" (adjusted $\mathrm{R}^{2}=0.61$ ) (see Table 4, Table 5 and Fig. 2). Thus, H1 and $\mathrm{H} 2$ are supported. However, results show that "Compatibility" $(\beta=0.073$, Standardized path coefficient, $\mathrm{p}<0.001)$ is not significant at $\mathrm{p}<0.001$ level. Hence, H3 is not supported.

Table 2. Cronbach's Alpha Reliability of Constructs in the Study

\begin{tabular}{|c|c|c|}
\hline Construct & Number of Items & $\begin{array}{c}\text { Cronbach's } \\
\text { Alpha }\end{array}$ \\
\hline Attitude & 3 & .912 \\
\hline $\begin{array}{c}\text { Subjective } \\
\text { Norm }\end{array}$ & 3 & .940 \\
\hline $\begin{array}{c}\text { Perceived } \\
\text { behavioural } \\
\text { control }\end{array}$ & 2 & .941 \\
\hline $\begin{array}{c}\text { Perceived } \\
\text { usefulness }\end{array}$ & 5 & .943 \\
\hline $\begin{array}{c}\text { Perceived Ease } \\
\text { of Use }\end{array}$ & 3 & .905 \\
\hline Compatibility & 2 & .876 \\
\hline Peer Influences & 3 & .981 \\
\hline $\begin{array}{c}\text { Superior } \\
\text { Influences }\end{array}$ & 4 & .979 \\
\hline Self-efficacy & 2 & .900 \\
\hline Income & 3 & .978 \\
\hline $\begin{array}{c}\text { Prior } \\
\text { Experience }\end{array}$ & 2 & .912 \\
\hline $\begin{array}{c}\text { Intention } \\
\text { Usage }\end{array}$ & 5038 \\
\hline Overall alpha & 2 & .989 \\
\hline
\end{tabular}

Table 3. KMO and Bartlett's Test

\begin{tabular}{|l|l|r|}
\hline \multicolumn{2}{|c|}{$\begin{array}{c}\text { Kaiser-Meyer-Olkin Measure of Sampling } \\
\text { Adequacy. }\end{array}$} \\
\hline Bartlett's Test of Sphericity & Approx. Chi-Square & 24608.548 \\
\cline { 2 - 3 } & df & 325 \\
\cline { 2 - 3 } & Sig. & .000 \\
\hline
\end{tabular}


Thereafter, "Peer Influences" and "Superior Influences" were regressed on "Subjective Norm". Results, as in Fig. 2 , indicate that "Peer Influences" $(\beta=0.427$, Standardized path coefficient, $\mathrm{p}<0.001)$ and "Superior
Influences" ( $\beta=0.165$, Standardized path coefficient, $p<$ $0.001)$ are significantly and positively related to "Subjective Norm" (adjusted $\mathrm{R}^{2}=0.260$ ) (see Table 4, Table 5 and Fig. 2). Thus, H4 and H5 are supported.

Table 4. Coefficients for Proposed model

\begin{tabular}{|c|c|c|c|c|c|c|c|}
\hline \multirow{2}{*}{$\begin{array}{l}\text { Dependent } \\
\text { variable }\end{array}$} & \multirow{2}{*}{$\begin{array}{c}\text { Path } \\
\text { direction }\end{array}$} & \multirow{2}{*}{$\begin{array}{l}\text { Independent variables } \\
\text { (predictors) }\end{array}$} & \multicolumn{2}{|c|}{$\begin{array}{l}\text { Unstandardized } \\
\text { Coefficients }\end{array}$} & \multirow{2}{*}{$\begin{array}{c}\text { Standardized Coefficients } \\
\text { Beta }\end{array}$} & \multirow[t]{2}{*}{$\mathrm{t}$} & \multirow[t]{2}{*}{ Sig. } \\
\hline & & & B & Std. Error & & & \\
\hline Attitude & $\leftarrow$ & Perceived usefulness & .289 & .025 & .312 & 11.325 & .000 \\
\hline Attitude & $\leftarrow$ & Perceived Ease of Use & .665 & .031 & .585 & 21.355 & .000 \\
\hline Attitude & $\leftarrow$ & Compatibility & .030 & .020 & .037 & 1.525 & .128 \\
\hline Subjective Norm & $\leftarrow$ & Peer Influences & .322 & .028 & .427 & 11.552 & .000 \\
\hline Subjective Norm & $\leftarrow$ & Superior Influences & .132 & .026 & .165 & 4.970 & .000 \\
\hline $\begin{array}{c}\text { Perceived } \\
\text { behavioural } \\
\text { control }\end{array}$ & $\leftarrow$ & Self-efficacy & .228 & .213 & .132 & 1.071 & .284 \\
\hline $\begin{array}{l}\text { Perceived } \\
\text { behavioural } \\
\text { control }\end{array}$ & $\leftarrow$ & Income & .062 & .029 & .083 & 2.151 & .032 \\
\hline $\begin{array}{c}\text { Perceived } \\
\text { behavioural } \\
\text { control } \\
\end{array}$ & $\leftarrow$ & Prior Experience & .182 & .211 & .106 & .864 & .388 \\
\hline Intention & $\leftarrow$ & Attitude & .621 & .034 & .636 & 18.191 & .000 \\
\hline Intention & $\leftarrow$ & Subjective Norm & .130 & .028 & .157 & 4.702 & .000 \\
\hline Intention & $\leftarrow$ & $\begin{array}{c}\text { Perceived behavioural } \\
\text { control }\end{array}$ & .046 & .017 & .077 & 2.659 & .008 \\
\hline Usage & $\leftarrow$ & Intention & .534 & .026 & .619 & 20.207 & .000 \\
\hline Usage & $\leftarrow$ & $\begin{array}{c}\text { Perceived behavioural } \\
\text { control }\end{array}$ & .048 & .017 & .073 & 2.779 & .006 \\
\hline
\end{tabular}

$\mathrm{P}$ values less than 0.001 were considered statistically significant

Table 5. Standardized Regression Weights

\begin{tabular}{|c|c|c|c|c|}
\hline Criterion variable & Path direction & Criterion variable predictors & Estimate & (Significance) \\
\hline Attitude & $\leftarrow$ & Perceived usefulness & .312 & Significant \\
\hline Attitude & $\leftarrow$ & Perceived Ease of Use & .585 & Significant \\
\hline Attitude & $\leftarrow$ & Compatibility & .037 & Insignificant \\
\hline Subjective Norm & $\leftarrow$ & Peer Influences & .427 & Significant \\
\hline Subjective Norm & $\leftarrow$ & Superior Influences & .165 & Significant \\
\hline Perceived behavioural control & $\leftarrow$ & Self-efficacy & .132 & Insignificant \\
\hline Perceived behavioural control & $\leftarrow$ & Income & .083 & Insignificant \\
\hline Perceived behavioural control & $\leftarrow$ & Prior Experience & .106 & Insignificant \\
\hline Intention & $\leftarrow$ & Attitude & .636 & Significant \\
\hline Intention & $\leftarrow$ & Subjective Norm & .157 & Significant \\
\hline Intention & $\leftarrow$ & Perceived behavioural control & .077 & Insignificant \\
\hline Usage & $\leftarrow$ & Intention & .619 & Significant \\
\hline Usage & $\leftarrow$ & Perceived behavioural control & .073 & Insignificant \\
\hline
\end{tabular}

Results also show that "Self-efficacy" $(\beta=0.132$, Standardized path coefficient, $p>0.001)$, "Income" $(\beta=$ 0.083 , Standardized path coefficient, $\mathrm{p}>0.001)$ and "Prior Experience" $(\beta=0.106$, Standardized path coefficient, $p>0.001)$ are not significant at $p<0.001$ level (see Table 4, Table 5 and Fig. 2). Hence, H6, H7 and H8 are not supported.

The three constructs (i.e. "Attitude", "Subjective Norm", and "Perceived behavioural control" were regressed on "Behavioral Intention". As in Fig. 2, it was found that "Attitude" $(\beta=0.636$, Standardized path coefficient, $p<0.001)$ and "Subjective Norm" $(\beta=0.157$,
Standardized path coefficient, $\mathrm{p}<0.001$ ) are significantly and positively related to "Behavioral Intention" (adjusted $\mathrm{R}^{2}=0.47$ ) (see Table 4, Table 5 and Fig. 2). Thus, H9 and H10 are supported. However, results show that "Perceived behavioural control" $(\beta=0.077$, Standardized path coefficient, $\mathrm{p}<0.001)$ is not significant at $\mathrm{p}<0.001$ level. Hence, H11 is not supported.

"Behavioral Intention" and "Perceived behavioural control" were regressed on "Usage Behavior". Results, as in Fig. 2, indicate that "Behavioral Intention" is significantly and positively related to "Usage Behavior" (adjusted $\left.\mathrm{R}^{2}=0.36\right)$ : "Behavioral Intention" $(\beta=0.619$, 
Standardized path coefficient, $\mathrm{p}<0.001)$. Thus, H12 is supported. However, results show that "Perceived behavioural control" ( $\beta=0.073$, Standardized path coefficient, $\mathrm{p}<0.001$ ) is not significant at $\mathrm{p}<0.001$ level (see Table 4, Table 5 and Fig. 2). Thus, H13 is not supported.

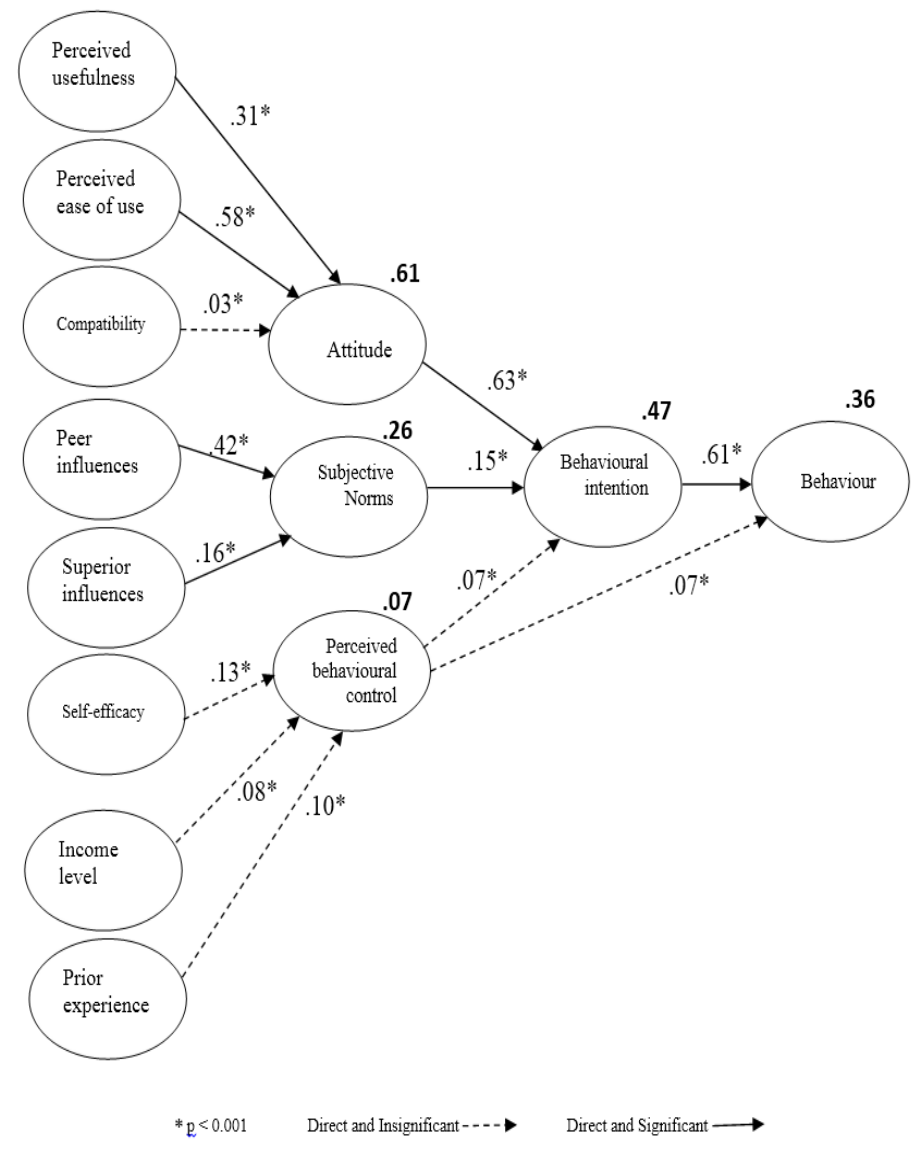

Fig.2. The study results (DTPB).

\section{DISCUSSION}

This study has been conducted to understand why people in Saudi Arabia adopt SNS, especially if we know that the trend to use and acceptance of technology is tremendously high, for example the number of mobile phone subscriptions reached 53 million in 2013, representing a population penetration rate of $181.6 \%$ ! [5] and total number of active Twitter users in the Arab world reached 5,797,500 users as of March 2014 and the country with the highest number of active Twitter users in the Arab region is Saudi Arabia with 2.4 million users, accounting for over $40 \%$ of all active Twitter users in the Arab region. The estimated number of tweets produced by Twitter users in the Arab world in March 2014 was $533,165,900$ tweets, an average of $17,198,900$ tweets per day [6]. Thus, the study aims to extend our understanding of the factors affecting the adoption of SNS as a new technology among Saudi people. Moreover, this study comes to help in covering the gap of research in the Middle East area more specifically in Saudi Arabia on how users of SNSs based on their behavioral influences intend to participating on SNS or not. For this purpose, the Decomposed Theory of Planned Behaviour is utilized.

The study results shows that adopter behaviour on SNSs determined by his or her "behavioural intention" which in turn is determined by his or her "attitude" and "subjective norms". The "attitude" significantly influenced by "Perceived Ease of Use" and "Perceived usefulness". While, "subjective norms" determined by "Peer Influences" and "Superior Influences". The model adopted in this study explains $47 \%$ of the variance in "Participation Intentions" and $36 \%$ of the variance in "Participation Behaviour".

The results show that "participation intention" is significantly and positively related to "participation behaviour" in the SNS context. Indeed, such a strong relation between the two constructs (i.e. IntentionBehaviour) concurs with many prior studies such as Taylor and Todd [28] study, according to their research, "behavioural intention plays an important substantive role, but is also important pragmatically in predicting behaviour" ([28], p. 165). Likewise, De Guinea and Markus [14] indicate that IT use behaviour is the result of conscious, cognitive behavioural intention. The importance of behavioural intention towards usage behaviour is also reported in other study to understand online community user participation by Zhou [32].

In this study, however, "perceived behavioural control" did not predict "participation behaviour", a finding that is not inconsistent with some studies such as Baker and 
White [7]. However this finding also concurs with other many studies (see [3]). This is consistent with the argument of Ajzen [1] which indicates that the strength of "perceived behavioural control" in predicting behaviour is dependent on perceptions of control being reflective of actual control. However in Internet use studies it seems unlikely that "perceived behavioural control" will reflect actual control accurately [22]. Thus, Inability of "perceived behavioural control" to predict "participation behaviour" refers to incapability "perceived behavioural control" to reflect actual control accurately.

\section{A. Understanding Behaviour}

The adopted model able to explain $36 \%$ of SNSs usage behavior. This ability relates to the diversity of the model's constructs and the diversity of relations among their constructs. In the model, behavioural intention is the primary, direct determinant of behaviour on the premise that "a person who intends to take a certain action is likely to carry out that behaviour" ([19], p. 742). However, the additional explanatory power afforded by the other relative factors. An equation has been formulated and used to calculate the participation of every model's construct in the model's explanatory power. The formula was applied to the model using the total (direct and indirect) effects of each model's construct on the SNSs usage behaviour (see Table6, Table7 and Table 8) as follow:

$$
A_{x}=\frac{\beta_{x}{ }^{2}}{\sum_{\mathrm{k}=1}^{\mathrm{n}} \beta_{\mathrm{x}}{ }^{2}} \times \mathrm{R}_{\mathrm{B}}{ }^{2}
$$

Where:

$A_{x}=$ Participation of variable $A_{x}$ in a model' explanatory power

$\beta_{x}{ }^{2}=$ Square of beta coefficients or standardized coefficients of variable

$\mathrm{R}_{\mathrm{B}}{ }^{2}=$ Model' explanatory power (behaviour)

$\sum_{k=1}^{n} \beta_{x}{ }^{2}=$ Total of causal effects for the model's constructs

Table 6. Decomposition of total causal effects for the model's constructs

\begin{tabular}{|c|rrrrrrrrrrrr|}
\hline & PEX & INC & PNF & SNF & SE & COM & PU & ES & PBC & SN & AT & BI \\
\hline PBC & .106 & .083 & .000 & .000 & .132 & .000 & .000 & .000 & .000 & .000 & .000 & .000 \\
SN & .000 & .000 & .427 & .165 & .000 & .000 & .000 & .000 & .000 & .000 & .000 & .000 \\
AT & .000 & .000 & .000 & .000 & .000 & .037 & .312 & .585 & .000 & .000 & .000 & .000 \\
BI & .008 & .006 & .070 & .027 & .010 & .004 & .013 & .453 & .077 & .157 & .636 & .000 \\
US & .005 & .004 & .042 & .016 & .006 & .002 & .008 & .271 & .073 & .099 & .383 & .619 \\
\hline
\end{tabular}

Table 7. Standardized Direct Effects

\begin{tabular}{|c|rrrrrrrrrrrr|}
\hline & PEX & INC & PNF & SNF & SE & COM & PU & ES & PBC & SN & AT & BI \\
\hline PBC & .106 & .083 & .000 & .000 & .132 & .000 & .000 & .000 & .000 & .000 & .000 & .000 \\
SN & .000 & .000 & .427 & .165 & .000 & .000 & .000 & .000 & .000 & .000 & .000 & .000 \\
AT & .000 & .000 & .000 & .000 & .000 & .037 & .312 & .585 & .000 & .000 & .000 & .000 \\
BI & .000 & .000 & .000 & .000 & .000 & .000 & .000 & .000 & .077 & .157 & .636 & .000 \\
US & .000 & .000 & .000 & .000 & .000 & .000 & .000 & .000 & .000 & .000 & .000 & .619 \\
\hline
\end{tabular}

Table 8. Standardized Indirect Effects

\begin{tabular}{|c|rrrrrrrrrrrr|}
\hline & PEX & INC & PNF & SNF & SE & COM & PU & ES & PBC & SN & AT & BI \\
\hline PBC & .000 & .000 & .000 & .000 & .000 & .000 & .000 & .000 & .000 & .000 & .000 & .000 \\
SN & .000 & .000 & .000 & .000 & .000 & .000 & .000 & .000 & .000 & .000 & .000 & .000 \\
AT & .000 & .000 & .000 & .000 & .000 & .000 & .000 & .000 & .000 & .000 & .000 & .000 \\
BI & .008 & .006 & .070 & .027 & .010 & .004 & .013 & .453 & .000 & .000 & .000 & .000 \\
US & .005 & .004 & .042 & .016 & .006 & .002 & .008 & .271 & .073 & .099 & .383 & .000 \\
\hline
\end{tabular}

Table 9 shows the participating model' variables and their explanatory power. In the adopted model, behavioural intention is the primary, direct determinant of behaviour and its participation in the model' explanatory power was the highest amongst the constructs. Behavioural intention was able to explain $14.6 \%$ of usage behaviour. This shows that behaviour is largely driven by behavioural intention and that has a notable impact on the model's explanatory power.

This impact can be obviously seen when behavioural intention is excluded from the model, since the prediction of behaviour decreases substantially (from $\mathrm{R}^{2}(\mathrm{~B})=0.36$ to $R^{2}(B)=0.21$. The drop in predictive power when behavioural intention was omitted concurs also with the Taylor and Todd [28] study, according to their research, "behavioural intention plays an important substantive role, but is also important pragmatically in predicting behaviour" ([28]. 165). Likewise, De Guinea and Markus [14] indicate that IT use behaviour is the result of conscious, cognitive behavioural intention.

Table 8 and 9 also show that "attitude" construct has a notable impact on usage behaviour, this impact came indirectly through its direct effect on behavioural intention. Participation of "attitude" in the models' explanatory power was the second highest amongst the constructs. "Attitude", alone explain around 9\% of SNSs usage behaviour.

Prior studies have shown that attitude positively influences behavioural intentions [2]. Attitude is is defined as an individual's feelings towards performing a 
specific behaviour, which is his positive or negative evaluation of performing the behaviour ([13], [1]). In other words, this construct refers to the general evaluations of an individual regarding the examined behaviour. In the context of this study, attitude is defined as the overall appraisals of individuals concerning participation on SNS.

Table 9. Participation of model's variables in the models' explanatory power

\begin{tabular}{|l|c|}
\hline \multicolumn{1}{|c|}{ Constructs } & The DTPB model \\
\hline Intention & $14.6 \%$ \\
\hline Attitude & $9 \%$ \\
\hline Perceived Ease of Use & $6.4 \%$ \\
\hline Subjective Norm & $2.3 \%$ \\
\hline Perceived behavioural control & $1.7 \%$ \\
\hline Peer Influences & $1 \%$ \\
\hline Superior Influences & $0.4 \%$ \\
\hline Perceived usefulness & $0.2 \%$ \\
\hline Self-efficacy & $0.14 \%$ \\
\hline Prior Experience & $0.12 \%$ \\
\hline Income & $0.09 \%$ \\
\hline Compatibility & $0.05 \%$ \\
\hline Total & $36 \%$ \\
\hline
\end{tabular}

The research findings also demonstrated that "Perceived Ease of Use" construct has a notable impact on usage behaviour (see Table 9), this impact came indirectly through its direct effect on "attitude". Actually impact of "perceived ease of use" on "attitude" confirms most prior studies ([12], [21], [31]) which found that "perceived ease of use" form the behavioural beliefs that influence individuals' attitude toward information technology, which in turn predicts their acceptance of IT. Moreover, the current study shows that participation of "Perceived Ease of Use" in the models' explanatory power was the third highest amongst the constructs. "Perceived Ease of Use", alone explain around 6.4\% of SNSs usage behaviour. This findings concurs with Choi and Chung study [11] which found that perceived usefulness and perceived ease of use had robust effects on the user's intention to use SNS [11].

The study findings also show that subjective norm has positive significant (.157) direct effects on intention to use SNSs. The result is consistent with the findings of Montesarchio [23]' study which found that subjective norm was positive explanatory variables of intent. Furthmore the result also is perfectly consistent with a study by Cheung and Lee which found that a stronger subjective norm leads to a higher level of intention to participate in an online social networking site [10]. This finding has been also confirmed by study of Al-Debei, et al., [3].

\section{CONCLUSIONS}

This study examines the individuals' participation intentions and behaviour on Social Networking Sites (SNSs). For this purpose, the Decomposed Theory of Planned Behaviour (DTPB) is utilized. Data collected from a survey of 1100 participants and distilled to 657 usable sets has been analysed to assess the predictive power of DTPB model via structural equation modelling. The results show that attitude and subjective norm have significant effect on the participation intention of adopters. Further, the results show that participation intention has significant effect on participation behaviour. However, the study findings also show that perceived behavioural control has no significant effect on participation intention or behaviour of adopters. The model adopted in this study explains $47 \%$ of the variance in "Participation Intentions" and $36 \%$ of the variance in "Participation Behaviour". Participation of behavioural intention in the model' explanatory power was the highest amongst the constructs (able to explain 14.6\% of usage behaviour). While, "attitude" explain around $9 \%$ of SNSs usage behaviour.

\section{IMPLICATIONS FOR THEORY AND PRACTICE}

\section{A. Implications for theory and research}

In the field of information systems, several IS models have been developed and applied to understand determinants of behavioural intention and usage behaviour. In particular, the current research addresses the behavioural intention and usage behaviour of SNSs users. This study contributes to the body of knowledge by exploring the behavioural and social factors affecting users' decisions to adopt SNSs as a new Information and Communication Technology (ICT); aiming to extend our understanding and knowledge in this domain. The present study also contributes to the Decomposed Theory of Planned Behaviour by providing a support for its efficacy in understanding and predicting people's use of SNSs.

Overall, this study provided some support for the application of the DTPB model in the context of highlevel SNS use with attitude and subjective norm significantly predicting intention, which, in turn, significantly predicted behaviour. Thus, there is a potential direction for future research to examine the impacts of additional constructs that might influence attitude toward SNS within the framework of DTPB. For instance investigate factors of social presence and social capital which might directly influence attitude toward SNS.

\section{B. Implications for practice}

The present study found that attitude construct indirectly influence usage behaviour through its direct effect on behavioural intention. This indicates that SNSs users, who have positive feeling or evaluation towards using the Internet and SNS' sites are more likely to adopt such services. This suggests that SNSs owners should develop effective strategies take into account the individuals' attitude by re-building policies and regulations which promote a positive feeling of individuals towards using SNSs.

In addition to importance of individuals' attitude, our findings also confirm that subjective norm has positive 
significant (.157) direct effects on intention to use SNSs, which suggests that perceived social pressure plays a critical role in SNS use. In other words, SNS users believe they are expected to use SNS by one or more important referents. Thus, individuals may choose to adopt SNSs if they believe one or more important referents think they should, even if they do not favor the SNSs or its consequences. This give us a thought that using SNS is inherently related to other people. For those who use SNS, managing social networks with SNS will be considered a universal trend; thus, the popularity of SNS is expected to encourage the users to participate in the same activity. Hence, SNSs' service providers, and developers should take this into their account.

\section{LIMITATIONS AND FURTHER RESEARCH}

A careful and systematic effort has been presented in this study to examine theory of planned behaviour in understanding and predicting people's use of SNSs. In order to strengthen the study a number of features such as a large sample size, actual measures of behaviour collected over time and a realistic setting were included. However, the present study has limits, it only considered intention and behaviour in the context of SNSs usage, and it is unclear whether the analytical results can be generalized to other areas of context in IS. The sample was collected in Saudi Arabia and generalisation of the study findings to other countries might be limited due to cultural differences in online user behaviours. Hence, the adopted model should be tested further using samples from other countries, thus future research is needed for a number of reasons in order to test the model further in SNS context.

Moreover, SNSs have differences in their features and interaction styles which might have an impact on motivation and intention; thus, it is strongly recommended that future research examine SNSs such as Twitter, Facebook or LinkedIn separately to account more specifically for the impacts of various DTPB constructs and getting more accurate results.

\section{REFERENCES}

[1] Ajzen, I. (1991). The theory of planned behaviour. Organizational Behaviour and Human Decision Processes, 50(2), 179-211.

[2] Ajzen, I., \& Fishbein, M. (1980). Understanding Attitudes and Predicting Social Behaviour. Englewood Cliffs, NJ: Prentice-Hall.

[3] Al-Debei, M., Al-Lozi, E., \& Papazafeiropoulou, A. (2013). Why people keep coming back to Facebook: Explaining and predicting continuance participation from an extended theory of planned behaviour perspective. Decision Support Systems, 55(1), 43-54.

[4] Alghaith, W., Sanzogni, L., Sandhu, K. (2010). Factors Influencing the Adoption and Usage of Online Services in Saudi Arabia. Electronic Journal of Information Systems in Developing Countries (EJISDC). 40(1), 1-32.

[5] Alotaibi, M. (2015). Mobile Computing Trends in Saudi Arabia: An Exploratory Study. I.J. Information Technology and Computer Science, 01, 21-32.
[6] Arab Social Media Report. (2014). Citizen Engagement and Public Services in the Arab World: The Potential of Social Media. Mohammed bin Rashid School of government, 1(6). Retrieved from Arab Social Media Report Website: http://www.arabsocialmediareport.com/

[7] Baker, R.K. \& White, K.M. (2010). Predicting adolescents' use of social networking sites from an extended theory of planned behaviour perspective. Computers in Human Behavior, 26, 1591-1597.

[8] Chen, A., Lu, Y., Chau, P. Y., \& Gupta, S. (2014). Classifying, Measuring, and Predicting Users' Overall Active Behavior on Social Networking Sites. Journal Of Management Information Systems, 31(3), 213-253.

[9] Chennamaneni, A., Teng, J. T., \& Raja, M. (2012). A unified model of knowledge sharing behaviours: theoretical development and empirical test. Behaviour \& Information Technology, 31(11), 1097-1115.

[10] Cheung, C. \& Lee, M. (2010). A theoretical model of intentional social action in online social networks, Decision Support Systems, 49(1), 24-30.

[11] Choi, G., \& Chung, H. (2013). Applying the Technology Acceptance Model to Social Networking Sites (SNS): Impact of Subjective Norm and Social Capital on the Acceptance of SNS. International Journal Of HumanComputer Interaction, 29(10), 619-628.

[12] Davis, F. D. (1989). Perceived usefulness, perceived ease of use, and user acceptance of information technology. MIS Quarterly, 13(3), 319-340.

[13] Davis, F. D., Bagozzi, R. P., \& Warshaw, P. R. (1989). User acceptance of computer technology: A comparison of two theoretical models. Management Science, 35, 9821003

[14] De Guinea, A., \& Markus, M. (2009). Why break the habit of a lifetime? rethinking the roles of intention, habit, and emotion in continuing information technology use. MIS Quarterly, 33(3), 433.

[15] Dholakia, U., Bagozzi, R., \& Pearo, L. (2004). A social influence model of consumer participation in network- and small-group-based virtual communities. International Journal of Research in Marketing, 21(3), 241-263.

[16] Ellison, N.B., Steinfield, C., \& Lampe, C. (2007). The benefits of Facebook "friends": social capital and college students' use of online social network sites. Journal of Computer-Mediated Communication, (12), 1143-1168.

[17] Gnyawali, D., Fan, W., \& Penner, J. (2010). Competitive actions and dynamics in the digital age: an empirical investigation of social networking firms. Information Systems Research. 21(3), 594-613.

[18] Hernandez, M. \& Mazzon, J. (2007). Adoption of internet banking: proposition and implementation of an integrated methodology approach. The International Journal of Bank Marketing, 25(2), 72-88.

[19] Kim, S., \& Malhotra, N. K. (2005). A Longitudinal Model of Continued IS Use: An Integrative View of Four Mechanisms Underlying Postadoption Phenomena. Management Science, 51(5), 741-755.

[20] Ku, Y.C., Chen, R., Zhang, H. (2013). Why do users continue using social networking sites? An exploratory study of members in the United States and Taiwan. Information \& Management, 50(7), 571-581.

[21] Ma, Q., \& Liu, L. (2004). The technology acceptance model: A meta-analysis of empirical findings. Journal of Organizational and End User Computing, 16(1), 59-72.

[22] Matute, H., Vadillo, M.A., Vegas, S. \& Blanco, F. (2007). Illusion of control in Internet users and college students. Cyberpsychology \& Behavior, 10, 176-181.

[23] Montesarchio, C. (2009). Factors influencing the unethical 
behavioral intention of college business students: Theory of planned behavior. Ph.D. dissertation, Lynn University, United States -- Florida.

[24] Moore, C., \& Benbasat, I. (2001). Development of an instrument to measure the perception of adopting an information technology innovation. Information Systems Research, 2(3), 192-222.

[25] Novak, T., Hoffman, D., \& Yung, Y. (2000). Measuring the customer experience in online environments: A structural modelling approach. Marketing Science, 19(1), $22-42$.

[26] Rogers, E. M. (2003). Diffusion of innovations (5th ed.). New York: Free Press.

[27] Sidorova, A., Evangelopoulos, N., Valacich, J. S., \& Ramakrishnan, T. (2008). Uncovering the intellectual core of the information systems discipline. MIS Quarterly, 32(3), 467-A20.

[28] Taylor, S., \& Todd, P.A. (1995). Understanding information technology usage: A test of competing models. Information Systems Research, 6(2), 144-176.

[29] Xu, C., Ryan, S., Prybutok, V., \& Wen, C. (2012). It is not for fun: An examination of social network site usage. Information and Management, 49(5), 210-217.

[30] Zhang, H., Lu, Y., Gupta, S., \& Zhao, L. (2014). What motivates customers to participate in social commerce? The impact of technological environments and virtual customer experiences, Information and Management, 51(8), 1017-103.

[31] Zhang, J. (2009). Exploring Drivers in the Adoption of Mobile Commerce in China. Journal of American Academy of Business, Cambridge, 15(1), 64-69.

[32] Zhou, T. (2011). Understanding online community user participation: a social influence perspective. Internet Research, 21(1), 67-81.

[33] Zikmund, W. G. (2003). Business research methods (7th ed.). Cincinnati, $\mathrm{OH}$ : Thomson.

\section{Authors' Profiles}

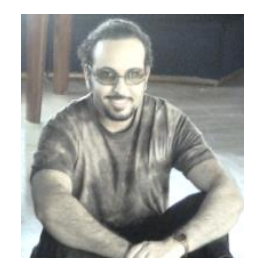

Waleed A. Alghaith is an Assistant Professor of Information systems at Shaqra University, Riyadh, Saudi Arabia. He holds a $\mathrm{PhD}$ in information systems from Griffith University, Australia. His areas of expertise are information technology research, internet research and organizational intelligence technologies. He currently works as Head of Information Systems Department, and as Dean of IT and eLearning deanship.

How to cite this paper: Waleed A. Al-Ghaith,"Applying Decomposed Theory of Planned Behaviour towards a Comprehensive Understanding of Social Network Usage in Saudi Arabia", International Journal of Information Technology and Computer Science(IJITCS), Vol.8, No.5, pp.52-61, 2016. DOI: $10.5815 /$ ijitcs.2016.05.06 